\title{
Trends in Childhood Morbidity and Mortality in the Era of Pandemic
}

\section{Joy Nkeiruka Ozughalu ${ }^{1}$, Angela Ezinne Orji ${ }^{2}$, Onyeka Chukwudalu Ekwebene ${ }^{3}$, Chidera Gabriel Edeh ${ }^{4}$}

\author{
${ }^{1}$ Institute of Public Health, College of Medicine, University of Nigeria, Enugu Campus, Nigeria \\ ${ }^{2}$ University Hospitals Coventry and Warwickshire NHS trust Coventry, UK. \\ ${ }^{3}$ Nnamdi Azikiwe University Teaching Hospital, Nnewi, Anambra State, Nigeria. \\ ${ }^{4}$ Faculty of Medicine, NnamdiAzikiwe University, Awka, Nnewi Campus. \\ Corresponding Author: Onyeka Chukwudalu Ekwebene
}

DOI: https://doi.org/10.52403/ijhsr.20220232

\begin{abstract}
Introduction: While there has been a steady decline in the rate of under-five mortality globally, subSaharan Africa still remains the region with the highest under-five mortality rate in the world, with 1 in 13 children dying before his or her fifth birthday. With the advent of the corona virus pandemic, the dynamism in the childhood morbidity pattern is certain. The objective of this study was to determine the morbidity patterns and outcomes of children seen in selected health care facilities in South-eastern Nigeria from March to October 2020.

Methodology: This study was a hospital-based retrospective study carried out in some health care facilities in South-eastern Nigeria. The study instrument was hospital records which were retrieved and relevant variables were collected from the records. The study population were children who were five years and below who had been admitted in the health facilities within the past eight months, from March-October, 2020. The data was analyzed using the Statistical Package for Social Science version 25. Descriptive analysis was computed whereby proportion/percentages and frequency was also calculated.

Result: The study found out among other childhood illnesses that; malaria, sepsis and PEM were the top three morbidities that led to hospitalization while $23.1 \%$ of children who were non-compliant with their immunization schedule, presented with bronchial pneumonia. The relationship between the age and trends in childhood illness was significant with p-value $\leq 0.05$.

Conclusion: Malaria still remains a major cause of hospitalization for children under the ages of five. Notwithstanding, the rate of admission of children into hospitals dropped significantly due to sanitary measures and awareness towards combating the spread of COVID-19 in its early days.
\end{abstract}

Keywords: under 5 children, pandemic, trends, childhood illnesses.

\section{INTRODUCTION}

As the global pandemic caused by the corona virus disease - COVID-19 sweeps through the planet earth, the death toll it leaves behind is unprecedented. Among the high risk groups as stated by the World Health Organization are the elderly, persons with underlying diseases such as diabetes, lung or heart diseases and other conditions that affect the immune system[1].
A study carried out in China reported that adverse health outcomes due to COVID-19 in children (below18 years) were minimal when compared to adults.[2] According to mortality and morbidity weekly reports by the US Centres for Disease Control, children under the age of 18 were less likely to experience the typical symptoms of COVID-19 infection including fever, cough and difficulty in breathing, and 
were less likely to need hospitalization and to die of the disease. In the reports, children of all ages appeared susceptible to COVID19, though over $90 \%$ of them had asymptomatic, mild or moderate cases. [3]

The index case of Coronavirus disease in Nigeria according to the Federal Ministry of Health was seen on February 27, 2020 [4] after which other cases sprung up in the country leading to a decision of lockdown of international airspace and other subsequent measures as deemed necessary at that time. These measures affected the educational sector as children have stayed home and indoors under the care of their parents or guardians for over four months.

During these periods of confinement, children had less contact with their external environment, reduced access to social activities (schooling. religious gatherings, leisure or fun outings, sporting events) and thus were less likely to come in contact with infectious contaminants lurking around in the surroundings. Parents also were more attentive and concerned about the welfare and well being of the children. Constant awareness and health education from health authorities, governmental and non-governmental organization through various media has stepped up the level of general hygiene especially hand hygiene in most homes. Parents were more than ever aware of the need to boost up immunity of their household members through proper nutrition.

Globally, there has been a steady decline in the rate of under-five mortality but sub-Saharan Africa still remains the region with the highest under-five mortality rate in the world, with 1 in 13 children dying before his or her fifth birthday. This mortality rate is 15 times higher than in high income countries. Acute respiratory infections, diarrheal diseases and malaria are among the leading causes of child mortality in sub-Saharan Africa [5].

Reports from the 2018 Nigeria Demographic and Health Survey showed that the under-five mortality rate in Nigeria is 132 per 1000 live births. This means that
1 in 8 children never reach the age of 5 years [6]. Much intervention is still needed if target 3.2 of the sustainable development goal 3 must be met [7]. The overall mortality rate in children as indicated in studies carried out in the south-south and south-west states of Nigeria are $4.1 \%$ and $5.1 \%$ respectively [8][9][10][11]

The leading causes of child morbidity, hospitalization and mortality as seen in previous studies carried out in Nigeria were malaria, diarrheal diseases, respiratory tract infection, sepsis, anaemia and measles [12][13].

With the knowledge and practice of various preventive measures, this study aims to understand the epidemiological trends of common diseases and their outcomes among children, five years and below whom were admitted into some health care facilities in South-eastern Nigeria.

\section{METHODOLOGY Study design}

This study was a hospital based retrospective study carried out in some selected health care institution in Southeastern Nigeria.

\section{Study Population}

The study population were children who were not above five years, who had been admitted in the health facilities within the past eight months from March-October, 2020.

\section{Exclusion criteria}

Children who were seen as outpatient, those admitted in the intensive care unit, neonates and those with incomplete records were excluded.

\section{Inclusion criteria}

Hospital records of children admitted within these periods and who met the inclusion criteria were perused to extract variables bordering on demographic status, diagnosis, date of admission, immunization status and outcome of management. 


\section{Data collection and Analysis}

After an optimal sample size appropriate for the study has been reached, the data was computed and analyzed using the Statistical Package for Social Science version 25. Descriptive analysis was computed whereby proportion/percentages and frequency was also calculated. Cross tabulation was used to establish the association between variables.

\section{ETHICAL CONSIDERATION}

The entirety of the study was clearly explained to the health care facilities and informed consent was also obtained. The health care facilities were assured of their confidentiality and anonymity of all information supplied for the study. Only health care facilities who gave their consent were given the opportunity. Ethical approval was also gotten from the various health care facilities in other for their data to be used in this study.

\section{RESULTS}

Table 1 Showing the Socio-Demographic Information of the Study Population

\begin{tabular}{|l|l|l|}
\hline Variable & Frequency & Percentage \\
\hline Age Group & & \\
\hline $1-12$ months & 66 & 44.0 \\
\hline $13-24$ months & 31 & 20.7 \\
\hline $25-36$ months & 19 & 12.7 \\
\hline $37-48$ months & 20 & 13.3 \\
\hline $49-60$ months & 14 & 9.3 \\
\hline $\begin{array}{l}\text { Mean Age } \pm \text { Std } \\
\text { Gender }\end{array}$ & $\mathbf{2 4 . 8 \pm 1 8 . 2}$ months & \\
\hline Female & 62 & 41.3 \\
\hline Male & 88 & 58.7 \\
\hline
\end{tabular}

Out of the 150 children studied, the age group 1-12 months of age were predominant with a frequency of 66 (44.0\%), followed by age groups 13-24 months and 37-48 months with frequencies of $31(20.7 \%)$ and $20(13.3 \%)$ respectively. The mean age of the children studied were $24.8 \pm 18.2$ months. The majority of the studied population were males $88(58.7 \%)$.

With regard to their immunization status, $79(52.7 \%)$ were compliant, while $45(30.0 \%)$ were still on it; however, $26(17.3 \%)$ were not complaint with their immunization schedule. With respect to presence of co-morbidities at presentation, majority do not have co-morbidities $141(94.0 \%)$. More of the children were admitted during the month of April $36(24.0 \%)$ and May 27(18.0\%). The least admission was around the months of June August 13(8.7\%) respectively and September $11(7.3 \%)$. Majority of the childhood illnesses that presented had good outcome 132(88.0\%).

Table 2 showing the immunization status, diagnosis, comorbidities, date of admission and outcome of management of the study population

\begin{tabular}{|c|c|c|}
\hline Variable & Frequency & Percentage \\
\hline \multicolumn{3}{|l|}{ Immunization Status } \\
\hline Compliant & 79 & 52.7 \\
\hline Non-compliant & 26 & 17.3 \\
\hline Still on it & 45 & 30.0 \\
\hline \multicolumn{3}{|c|}{ Childhood Illnesses that Presented } \\
\hline Anemic Heart Failure & 4 & 2.7 \\
\hline Acute Gastroenteritis & 4 & 2.7 \\
\hline Asthma Attack & 6 & 4.0 \\
\hline Bronchial Pneumonia & 11 & 7.3 \\
\hline Intussusception & 5 & 3.3 \\
\hline Malaria & 54 & 36.0 \\
\hline Meningitis & 10 & 6.7 \\
\hline PEM & 22 & 14.7 \\
\hline Sepsis & 32 & 21.3 \\
\hline SCD & 2 & 1.3 \\
\hline \multicolumn{3}{|l|}{ Co-morbidities } \\
\hline Non & 141 & 94.0 \\
\hline Delayed Milestone & 9 & 6.0 \\
\hline \multicolumn{3}{|l|}{ Date of Admission } \\
\hline March & 18 & 12.0 \\
\hline April & 36 & 24.0 \\
\hline May & 27 & 18.0 \\
\hline June & 13 & 8.7 \\
\hline July & 13 & 8.7 \\
\hline August & 13 & 8.7 \\
\hline September & 11 & 7.3 \\
\hline $\begin{array}{l}\text { October } \\
\text { Outcome of Management }\end{array}$ & 19 & 12.7 \\
\hline Good & 132 & 88.0 \\
\hline $\mathrm{Bad}$ & 18 & 12.0 \\
\hline
\end{tabular}

Table 3 shows that malaria $54(36.0 \%)$, sepsis $32(21.3 \%)$ and PEM $22(14.7 \%)$ were the top three disease outcome seen in hospitalised children during the study. The age group 1-12 months presented more with sepsis 23(34.8\%), malaria 13(19.7\%), PEM $10(15.2 \%)$, bronchial pneumonia $8(12.1 \%)$ and intussusception 5(7.6\%). Anaemic heart failure was more prevalent among the age group 37-48 months. The relationship between the age and trends in childhood illness was significant with $p$-value $\leq 0.05$. 
Table 3: Disease Outcomes versus Age and Gender

\begin{tabular}{|c|c|c|c|c|c|c|c|c|c|c|c|c|c|c|c|}
\hline \multicolumn{7}{|l|}{ AGE GROUP } & \multirow{2}{*}{\begin{tabular}{|l|} 
Chi- \\
square \\
$\left(x^{2}\right)$ \\
\end{tabular}} & \multirow{2}{*}{ df } & \multirow[b]{2}{*}{$\begin{array}{l}\text { p- } \\
\text { value } \\
(\leq 0.05)\end{array}$} & \multicolumn{3}{|c|}{ GENDER } & \multirow[b]{2}{*}{$\begin{array}{l}\text { Chi- } \\
\text { square } \\
\left(\chi^{2}\right)\end{array}$} & \multirow[b]{2}{*}{ df } & \multirow[b]{2}{*}{$\begin{array}{l}\text { p- } \\
\text { value } \\
(\leq 0.05) \\
\end{array}$} \\
\hline & $\begin{array}{l}1 \text {-12 } \\
\text { months }\end{array}$ & $\begin{array}{l}\text { 13-24 } \\
\text { months }\end{array}$ & $\begin{array}{l}25-36 \\
\text { months }\end{array}$ & $\begin{array}{l}\text { 37-48 } \\
\text { months }\end{array}$ & $\begin{array}{l}49-60 \\
\text { months }\end{array}$ & Total & & & & Male & Female & Total & & & \\
\hline $\begin{array}{l}\text { Anemic Heart } \\
\text { Failure No. }(\%)\end{array}$ & $0(0.0)$ & $0(0.0)$ & $\begin{array}{l}1 \\
(5.3)\end{array}$ & $\begin{array}{l}3 \\
(15.0) \\
\end{array}$ & $\begin{array}{l}0 \\
(0.0) \\
\end{array}$ & $\begin{array}{l}4 \\
(2.7)\end{array}$ & 83.1 & 36 & 0.00 & $\begin{array}{l}1 \\
(1.1)\end{array}$ & $\begin{array}{l}3 \\
(4.8)\end{array}$ & $\begin{array}{l}4 \\
(2.7) \\
\end{array}$ & 12.3 & 9 & 0.19 \\
\hline $\begin{array}{l}\text { Acute Gastroenteritis } \\
\text { No. }(\%)\end{array}$ & $1(1.5)$ & $\begin{array}{l}1 \\
(3.2)\end{array}$ & $\begin{array}{l}2 \\
(10.5)\end{array}$ & $0(0.0)$ & $0(0.0)$ & $\begin{array}{l}4 \\
(2.7)\end{array}$ & & & & $\begin{array}{l}2 \\
(2.3)\end{array}$ & $\begin{array}{l}2 \\
(3.2)\end{array}$ & $\begin{array}{l}4 \\
(2.7) \\
\end{array}$ & & & \\
\hline $\begin{array}{l}\text { Asthmatic Attack } \\
\text { No. }(\%)\end{array}$ & $\begin{array}{l}2 \\
(3.0) \\
\end{array}$ & $\begin{array}{l}4 \\
(12.9)\end{array}$ & $\begin{array}{l}0 \\
(0.0) \\
\end{array}$ & $0(0.0)$ & $0(0.0)$ & $\begin{array}{l}6 \\
(4.0) \\
\end{array}$ & & & & $\begin{array}{l}2 \\
(2.3) \\
\end{array}$ & $\begin{array}{l}4 \\
(6.5) \\
\end{array}$ & $\begin{array}{l}6 \\
(4.0) \\
\end{array}$ & & & \\
\hline $\begin{array}{l}\text { Bronchial } \\
\text { Pneumonia } \\
\text { No. }(\%)\end{array}$ & $\begin{array}{l}8 \\
(12.1)\end{array}$ & $\begin{array}{l}2 \\
(6.5)\end{array}$ & $1(5.3)$ & $0(0.0)$ & $0(0.0)$ & $\begin{array}{l}11 \\
(7.3)\end{array}$ & & & & $\begin{array}{l}9 \\
(10.2)\end{array}$ & $\begin{array}{l}2 \\
(3.2)\end{array}$ & $\begin{array}{l}11 \\
(7.3)\end{array}$ & & & \\
\hline $\begin{array}{l}\text { Intussusception } \\
\text { No. }(\%) \\
\end{array}$ & $\begin{array}{l}5 \\
(7.6) \\
\end{array}$ & $0(0.0)$ & $0(0.0)$ & $0(0.0)$ & $0(0.0)$ & $\begin{array}{l}5 \\
(3.3) \\
\end{array}$ & & & & $\begin{array}{l}4 \\
(4.5) \\
\end{array}$ & $\begin{array}{l}1 \\
(1.6) \\
\end{array}$ & $\begin{array}{l}5 \\
(3.3) \\
\end{array}$ & & & \\
\hline $\begin{array}{l}\text { Malaria/Plasmodiasis } \\
\text { No. }(\%)\end{array}$ & $\begin{array}{l}13 \\
(19.7)\end{array}$ & $\begin{array}{l}13 \\
(41.9)\end{array}$ & $\begin{array}{l}7 \\
(36.8)\end{array}$ & $\begin{array}{l}10 \\
(50.0)\end{array}$ & $\begin{array}{l}11 \\
(78.6)\end{array}$ & $\begin{array}{l}54 \\
(36.0)\end{array}$ & & & & $\begin{array}{l}32 \\
(36.4)\end{array}$ & $\begin{array}{l}22 \\
(35.5)\end{array}$ & $\begin{array}{l}54 \\
(36.0)\end{array}$ & & & \\
\hline $\begin{array}{l}\text { Meningitis } \\
\text { No. }(\%)\end{array}$ & $\begin{array}{l}4 \\
(6.1)\end{array}$ & $0(0.0)$ & $\begin{array}{l}2 \\
(10.5)\end{array}$ & $\begin{array}{l}2 \\
(10.0)\end{array}$ & $\begin{array}{l}2 \\
(14.3)\end{array}$ & $\begin{array}{l}10 \\
(6.7) \\
\end{array}$ & & & & $\begin{array}{l}7 \\
(8.0) \\
\end{array}$ & $\begin{array}{l}3 \\
(4.8) \\
\end{array}$ & $\begin{array}{l}10 \\
(6.7) \\
\end{array}$ & & & \\
\hline $\begin{array}{l}\text { PEM } \\
\text { No. }(\%)\end{array}$ & $\begin{array}{l}10 \\
(15.2)\end{array}$ & $\begin{array}{l}8 \\
(25.8)\end{array}$ & $\begin{array}{l}3 \\
(15.8)\end{array}$ & $1(5.0)$ & $0(0.0)$ & $\begin{array}{l}22 \\
(14.7)\end{array}$ & & & & $\begin{array}{l}11 \\
(12.5)\end{array}$ & $\begin{array}{l}11 \\
(17.7)\end{array}$ & $\begin{array}{l}22 \\
(14.7)\end{array}$ & & & \\
\hline $\begin{array}{l}\text { Sepsis } \\
\text { No. }(\%)\end{array}$ & $\begin{array}{l}23 \\
(34.8) \\
\end{array}$ & $\begin{array}{l}1 \\
(3.2) \\
\end{array}$ & $\begin{array}{l}3 \\
(15.8) \\
\end{array}$ & $\begin{array}{l}4 \\
(20.0) \\
\end{array}$ & $\begin{array}{l}1 \\
(7.1) \\
\end{array}$ & $\begin{array}{l}32 \\
(21.3)\end{array}$ & & & & $\begin{array}{l}18 \\
(20.5)\end{array}$ & $\begin{array}{l}14 \\
(22.6)\end{array}$ & $\begin{array}{l}32 \\
(21.3)\end{array}$ & & & \\
\hline $\begin{array}{l}\text { SCD } \\
\text { No. }(\%)\end{array}$ & $0(0.0)$ & $2(6.5)$ & $0(0.0)$ & $0(0.0)$ & $0(0.0)$ & $\begin{array}{l}2 \\
(1.3)\end{array}$ & & & & $\begin{array}{l}2 \\
(2.3) \\
\end{array}$ & $\begin{array}{l}0 \\
(0.0)\end{array}$ & $\begin{array}{l}2 \\
(1.3)\end{array}$ & & & \\
\hline Total & $\begin{array}{l}66 \\
(100.0)\end{array}$ & $\begin{array}{l}31 \\
(100)\end{array}$ & $\begin{array}{l}19 \\
(100)\end{array}$ & $\begin{array}{l}20 \\
(100.0)\end{array}$ & $\begin{array}{l}14 \\
(100.0)\end{array}$ & $\begin{array}{l}150 \\
(100)\end{array}$ & & & & $\begin{array}{l}88 \\
(100.0)\end{array}$ & $\begin{array}{l}62 \\
(100.0)\end{array}$ & $\begin{array}{l}150 \\
(100.0)\end{array}$ & & & \\
\hline
\end{tabular}


With respect to the relationship between gender and childhood illnesses, the male presented more with malaria $32(36.4 \%)$, sepsis $18(20.5 \%)$, PEM $11(12.5 \%)$, bronchial pneumonia $9(10.2 \%)$, meningitis $7(8.0 \%)$ and intussusception $4(4.5 \%)$. The female however presented more with Asthmatic attack 4(6.5\%) and Anaemic heart failure $3(4.8 \%)$. The least childhood illness that presented during this period was sickle cell disease (SCD) $2(1.3 \%)$. The relationship between gender and trends in childhood illness was not statistically significant ( $P$-value $\geq 0.05$ ).

Table 4: Disease Outcome and Immunization Statuses

\begin{tabular}{|c|c|c|c|c|c|c|c|}
\hline \multicolumn{5}{|l|}{ Immunization Status } & \multirow[b]{2}{*}{ Chi-square $\left(x^{2}\right)$} & \multirow[b]{2}{*}{ Df } & \multirow[b]{2}{*}{ p-value $(\leq 0.05)$} \\
\hline & Non - compliant & Compliant & Still on it & Total & & & \\
\hline Anemic Heart Failure No. (\%) & $0(0.0)$ & $4(5.1)$ & $0(0.0)$ & $4(2.7)$ & 70.9 & 18 & 0.00 \\
\hline Acute Gastroenteritis No. (\%) & $1(3.8)$ & $2(2.5)$ & $1(2.2)$ & $4(2.7)$ & & & \\
\hline Asthmatic Attack No. (\%) & $0(0.0)$ & $6(7.6)$ & $0(0.0)$ & $6(4.0)$ & & & \\
\hline Bronchial Pneumonia No. (\%) & $6(23.1)$ & $3(3.8)$ & $2(4.4)$ & $11(7.3)$ & & & \\
\hline Intussusception No. (\%) & $0(0.0)$ & $1(1.3)$ & $4(8.9)$ & $5(3.3)$ & & & \\
\hline Malaria/Plasmodiasis No. (\%) & $6(23.1)$ & $43(54.4)$ & $5(11.1)$ & $54(36.0)$ & & & \\
\hline Meningitis No. (\%) & $3(11.5)$ & $6(7.6)$ & $1(2.2)$ & $10(6.7)$ & & & \\
\hline PEM No. (\%) & $5(19.2)$ & $9(11.4)$ & $8(17.8)$ & $22(14.7)$ & & & \\
\hline Sepsis No. (\%) & $5(19.2)$ & $4(5.1)$ & $23(51.1)$ & $32(21.3)$ & & & \\
\hline SCD No. (\%) & $0(0.0)$ & $1(1.3)$ & $1(2.2)$ & $2(1.3)$ & & & \\
\hline Total & $26(100.0)$ & $79(100.0)$ & $45(100.0)$ & $150(100.0)$ & & & \\
\hline
\end{tabular}

Table 4 shows that $23.1 \%$ of those not complaint with their immunization schedule presented with bronchial pneumonia and malaria respectively, however those that were compliant with their immunization schedule still presented with malaria 43(54.4\%), PEM 9(11.4\%), Asthmatic attack 6(7.6\%), meningitis $6(7.6 \%)$, Anaemic heart failure 4(5.1\%) and Acute gastroenteritis 2(2.5\%). Approximately $51 \%$ of those still on their vaccine regimen presented with sepsis. The association between immunization status and trends in childhood illness among the study population was statistically significant with $\mathrm{p}$-value $\leq 0.05$.

\section{DISCUSSION}

The unequal distributions of childhood admissions among the boys and girls as observed in this study was in tandem with the findings by Abhulimhen-Iyoha and Okolo [14] in Benin and Ibeziako and Ibekwe [15] in Enugu, respectively where male admissions were predominant. However, the reason for the variations has not been ascertained, it may be due to regional variation in the health seeking behavior on behalf of children for socio cultural reasons of attaching more value to male children. [16]
Ninety-four percent of the children studied did not have co-morbidities. More of the children were admitted during the month of April and May. This was at the beginning of the lockdown period when COVID-19 cases were still minimal and the level of fear was gradually mounting. The next four month saw a reduction in the rate of admission as most household resorted to alternative medicine with the collapse of economic activities, which distorted income flow and purchasing power. Majority of the children had good outcome with full recovery and therefore duly discharged. However, a few of the children had bad outcomes ranging from delayed milestones, severe weight loss to mortality.

Malaria, Sepsis and PEM were the top three morbidities seen in the study population. This finding is similar to findings by some studies from Nigeria [16][17] and Mozambique,[18] were the most common causes of morbidity in children. The least childhood illness that presented during this period was Sickle cell disease. This may be highly expected given the various educational interventions on genotype to enlighten adults of reproductive age.

Of all the age groups studied, age 112 months presented more with sepsis, PEM, malaria, bronchopneumonia and 
intussusception. This might possibly be non compliant of mothers to exclusive breast feeding thereby denying this young age groups the benefits of exclusive breast milk.

Results from the analysis done on immunization status and childhood illnesses showed that children who were not complaint with their immunization schedule presented more with bronchial pneumonia. Childhood immunization remains the safest preventive intervention that protects against diseases.

\section{CONCLUSIONS}

Protective measures like exclusive breastfeeding, adequate complementary feeding, immunizations, reduced household air pollution, safe drinking water, sanitation, hygiene and vitamin A supplementation provide the foundation for keeping children healthy and free of disease. Efforts should be made to design appropriate health care model that would facilitate a considerable reduction in childhood morbidity in the country

\section{ACKNOWLEDGMENTS}

The authors hereby acknowledge all the health care facilities who allowed their facilities data to be used for this study.

\section{Conflict Of Interest}

The authors declared that there is no conflict of interest.

\section{Source of Funding: None}

\section{Ethical Approval: Approved}

\section{REFERENCES}

1. World Health Organization (WHO) COVID-19: Vulnerable and high risk group. Available from: https://www.who.int/westernpacific/emerge ncies/covid-19/information/high-risk-groups

2. Dong Y, Mo X, Hu Y, Qi X, Jiang F, Jiang Z, Tong S. Epidemiological characteristics of 2143 pediatric patients with 2019 coronavirus disease in China. Pediatrics. 2020 Mar 1
3. Coronavirus Disease 2019 in Children United States, February 12-April 2, 2020. MMWR Morb Mortal Wkly Rep 2020;69:422-426. DOI: http://dx.doi.org/10.15585/mmwr.mm6914e 4

4. Nigeria Centre for Disease Control. COVID-19 Outbreak in Nigeria: Situation Reports. 2020. Available from: https://ncdc.gov.ng/diseases/sitreps

5. World Health Organization. Children: Reducing mortality. Geneva: World Health Organization,

2019.URL:http://www.who.int/newsroom/fact-sheets/detail/children-reducing/

6. National Population Commission NPC/Nigeria and ICF. 2019. Nigeria Demographic and Health Survey 2018. Abuja, Nigeria, and Rockville, Maryland, USA: NPC and ICF.

7. UN General Assembly, Transforming our world: the 2030 Agenda for Sustainable Development, $21 \quad$ October 2015, A/RES/70/1, available at: https://www.refworld.org/docid/57b6e3e44 Accessed 3 August 2020.

8. Onyiriuka AN. Morbidity and mortality patterns of post-neonatal paediatric medical admissions in a large mission hospital in Benin City, Nigeria. J Biomed Sci 2005; 4(1): 49-58.

9. Ndukwu CI, Onah S K. Pattern and outcome of post-neonatal pediatric emergencies in NnamdiAzikiwe University Teaching Hospital, Nnewi, South East Nigeria. Niger J ClinPract 2015; 18: 348-53.

10. Ezeonwu B, Chima O, Oguonu T, Ikefuna A, Nwafor I. Morbidity and mortality pattern of childhood illnesses seen at the children emergency unit of federal medical center, asaba, Nigeria. Ann Med Health Sci Res. 2014;4(Suppl 3):S239-S244. doi:10.4103/2141-9248.141966

11. Ominla SO, Fadugbagbe AO, Oninla OA, Otetubi OA. Pattern of childhood morbidities and outcome of childhood admissions in a Nigerian public secondary healthcare facility. Ann health res. 2018;4:162-73.

12. Sarkar, Dr.Jhuma, Dr.Abantika Bhattacharya, Dr.BaijayantiBaur, Dr. Manabendra Sau. Morbidity Pattern And Some Socio-Cultural Factors: A Study Amongst Under Five Children Attending Pediatric Department Of A Tertiary Care 
Hospital In West Bengal, India. Journal of Dental and Medical Science. 2016;15(6): 41-5.

13. Abhulimhen-Iyoha BI, Okolo AA. Morbidity and mortality of childhood illnesses at the emergency paediatric unit of the University of Benin Teaching Hospital, Benin City. Niger J Paed 2012;39:71-4.

14. Ibeziako SN, Ibekwe RC. Pattern and outcome of admissions in the Children's Emergency Room of the University of Nigeria Teaching Hospital, Enugu. Niger J Paediatr 2002; 29:103-7.

15. Sacarlal J, Nhacolo AQ, Sigaúque B, Nhalungo DA, Abacassamo F, Sacoor $\mathrm{CN}$, et al. A 10 year study of the cause of death in children under 15 years in Manhiça, Mozambique. BMC Public Health 2009;9:67.

16. Duru C, Peterside O, AkimbamiF.Pattern and outcome of admissions as seen in the PaediatricEmergency Ward of the Niger
Delta University Teaching Hospital Bayelsa State, Nigeria. Niger J Paediatr 2013; 40:232-7.

17. Mouneke UV, Ibekwe RC, Eke CB, Ibekwe MU, Chinawa JM. Mortality among paediatric inpatients in Mile 4 Mission Hospital Abakaliki, south-eastern Nigeria: A retrospective study. Niger $J$ Paediatr 2013; 40:259-63.

18. Sacarlal J, Nhacolo AQ, Sigaúque B, Nhalungo DA, Abacassamo F, Sacoor $\mathrm{CN}$, et al. A 10 year study of the cause of death in children under 15 years in Manhiça, Mozambique. BMC Public Health 2009; 9:67.

How to cite this article: Joy Nkeiruka Ozughalu, Angela Ezinne Orji, Onyeka Chukwudalu Ekwebene et.al. Trends in childhood morbidity and mortality in the era of pandemic. Int $J$ Health Sci Res. 2022; 12(2): 227-233. DOI: https://doi.org/10.52403/ijhsr.20220232 